\title{
ANALYSIS OF THE STATE OF AMBIENT AIR IN THE BORDER REGION BULGARIA - ROMANIA
}

Margarita Filipova $^{1}$, Ivanka Zheleva ${ }^{1}$, Petar Rusev $^{1}$, Antoaneta Stefanova $^{1}$, Irina Tcvetanova ${ }^{1}$

${ }^{1}$ Ruse University Angel Kanchev, 8 Studentska, Ruse, Bulgaria

\begin{abstract}
Air pollution has a significant impact on human health, environment and economy. Air pollution comes from a variety of sources including the industry, transport and agriculture. Every day, air pollution causes respiratory and cardiovascular diseases. The pollution causes damages of ragile ecosystems and biodiversity. It also reduces the yield of crops and commercial forest yields. Therefore, it is vital to take action both at home and together with other countries - across borders and sectors.

Air pollution by sulfur dioxide, nitrogen oxides, ammonia, non-methane volatile organic compounds and particulate matter create the most serious problems for human health and they are the main reason for the deterioration of ecosystems. These air pollutants in the border area Bulgaria - Rumania are presented and analyzed in the present paper.
\end{abstract}

Key words: air pollution, pollutants, monitoring system

\section{Characteristics and basic pollutants in the border region Bulgaria - Romania}

Environmental challenges in the border region Bulgaria - Romania are numerous and they are interrelated. Emissions of hazardous chemicals, climate change, efficient public involvement in decision-making and access to environmental information and justice are among the major concerns that need to take urgent action to protect the purity of the air. The problems in the border region are common and their solutions have to be also common

It is well known that the new Cross Border Cooperation Program Romania-Bulgaria will act in the 2014-2020 period [1]. The cross border region Romania - Bulgaria is shown in Figure 1.

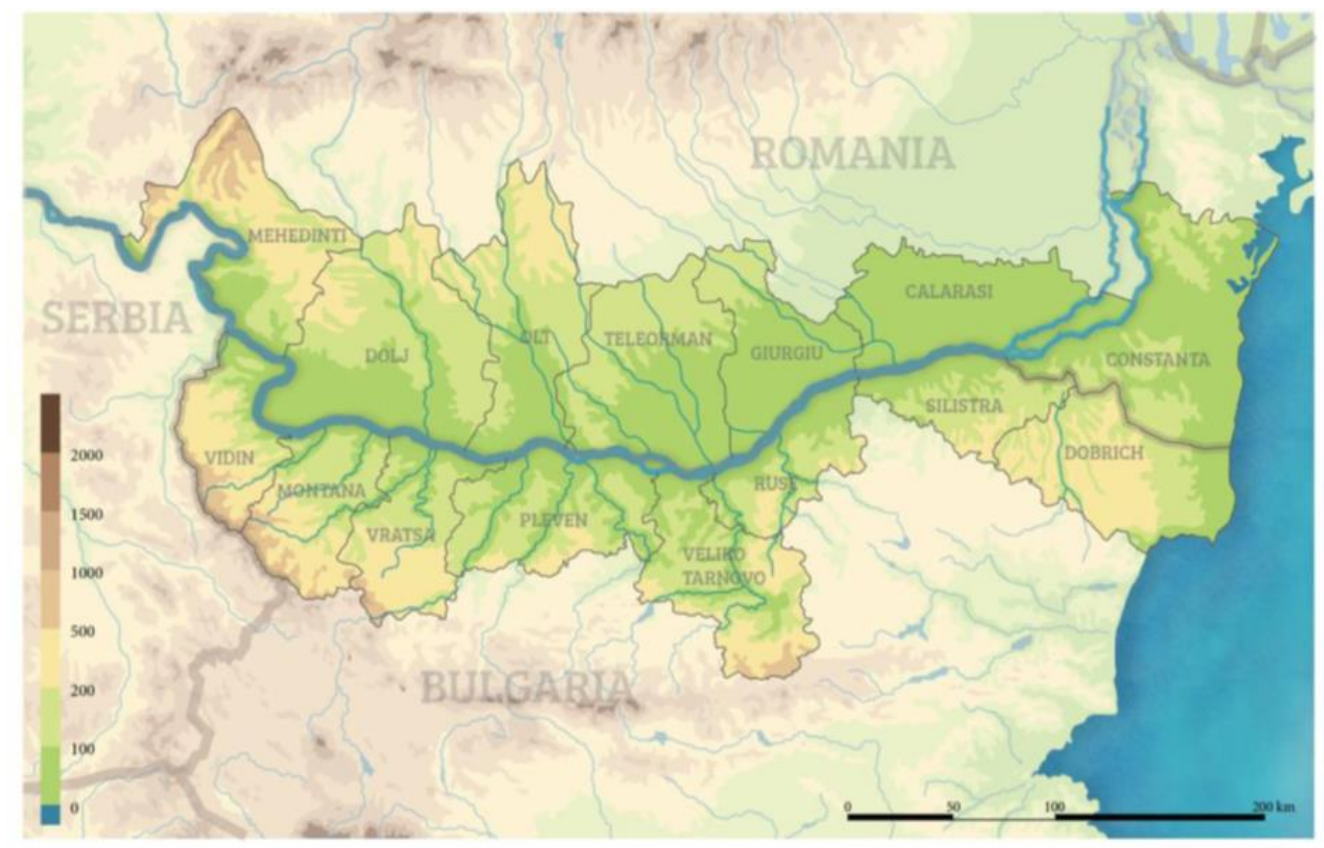

Figure 1.Trans border region Romania - Bulgaria 
One of the main problems identified in this program is to enhance the sustainable management of ecosystems in the border region. This is directly related with the protection of the air clean.

Main monitored pollutants for both Bulgarian and Romanian sections are: sulfur dioxide $\left(\mathrm{SO}_{2}\right)$, nitrogen oxides $\left(\mathrm{NO}_{2}\right)$ and nitrogen oxides $\left(\mathrm{NO}_{x}\right)$, carbon monoxide $(\mathrm{CO})$, ozone $\left(\mathrm{O}_{3}\right)$, volatile organic compounds, benzene and particulate matter (PM10 and PM2.5).

In the Bulgarian system for monitoring the air quality 54 monitoring points are included of which 34 are automatic measuring stations (AMS), 10 are Differential Optical Absorption Spectroscopy (DOAS), and 10 are with manual sampling. The system of air quality monitoring has got also 6 Mobile Automatic Stations (MAS) connected with the regional laboratories in Sofia, Plovdiv, Pleven, Stara Zagora, Varna and Ruse. According to the Clean Air Act the main indicators characterizing the air quality at ground level are: suspended particulates, particulate matter, sulfur dioxide, nitrogen dioxide and / or nitrogen oxides, carbon monoxide, ozone, lead, benzene, polycyclic aromatic hydrocarbons and heavy metals (cadmium, nickel arsenic and mercury). Requirements of Directive 2008/50 / EC on ambient air quality and cleaner air for Europe [2] is transposed into national law by Ordinance № 12 (2010) of the Bulgarian Ministry of Environment and Water and the Ministry of Health [3].

For 2013 in Romania there are 138 monitoring points for air quality, which are equipped with automatic measurement sets for key air pollutants [4]. They are a part of a national network for air quality monitoring (RNMCA) and are distributed throughout the country in accordance with the criteria set out in EU directives in the field of air quality.

To protect human health sampling of air are carried out so as to provide data according to the following:

- determining the locations where the highest concentrations of a harmful substance are found. For these locations it is likely the population to be directly or indirectly exposed to these substances for a significant period of time;

- determining the pollution levels which are representative of the exposure of the population;

- determining deposit values that the population have indirect exposure to through the food chain.

\section{National systems for air quality control}

Romania national network for air quality monitoring - (RNMCA) allows quick access for informing the population for all regions of the country. Visual informing the public about the air quality in this system is done by the so called "specific indices ". These indexes are represented numerically or by colors for the main mentioned pollutants. The value of the specific index depends on the concentration of the pollutant (see Table 1). The higher concentration of the pollutant leads to the higher value of the specific index. To calculate the overall index for a point one should take into account at least three indicators of prevailing monitored pollutants. The indices are represented by integers between 1 and 6 . Each number corresponds to a particular color (Fig. 2).

The monitoring of air quality in Bulgaria is carried out by the National Monitoring System. The concentrations of the main indicators cited above are daily monitored. Additionally according to the nature and the sources of emissions in certain regions of the country some extra specific indicators as ammonia, aerosols of sulfuric acid, toluene, xylene, styrene, hydrogen sulfide, methane and non-methane hydrocarbons are also controlled. 
Table1. Specific indices and their values for some pollutants in Romania [5]

\begin{tabular}{|c|c|c|c|c|c|}
\hline $\begin{array}{l}\text { Specific } \\
\text { indices }\end{array}$ & $\begin{array}{c}\text { Sulfur } \\
\text { dioxide } \\
\mathrm{SO}_{2}, \mu \mathrm{g} / \mathrm{m}^{3}\end{array}$ & $\begin{array}{l}\text { Nitrogen } \\
\text { dioxide } \\
\mathrm{NO}_{2}, \mu \mathrm{g} / \mathrm{m}^{3}\end{array}$ & $\begin{array}{c}\text { Ozone } \\
\mathrm{O}_{3}, \mu \mathrm{g} / \mathrm{m}^{3}\end{array}$ & $\begin{array}{c}\text { Carbon } \\
\text { monoxide } \\
\mathrm{CO}, \mu \mathrm{g} / \mathrm{m}^{3}\end{array}$ & $\begin{array}{l}\mathrm{PM} 10 \\
\mu \mathrm{g} / \mathrm{m}^{3}\end{array}$ \\
\hline 1 & $0-49.9$ & $0-49.9$ & $0-39.9$ & $0-2.9$ & $0-9.9$ \\
\hline 2 & $50-74.9$ & $50-99.9$ & $40-79.9$ & $3-4.9$ & $10-19.9$ \\
\hline 3 & $75-124.5$ & $100-139.9$ & $80-119.9$ & $5-6.9$ & $20-29.9$ \\
\hline 4 & $125-349.9$ & $140-199.9$ & $120-179.9$ & $7-9.9$ & $30-49.9$ \\
\hline 5 & $350-499.9$ & $200-399.9$ & $180-239.9$ & $10-14.9$ & $50-99.9$ \\
\hline 6 & $>500$ & $>400$ & $>240$ & $>15$ & $>100$ \\
\hline
\end{tabular}

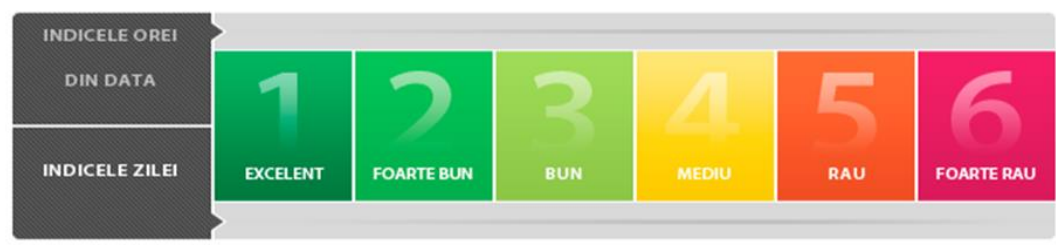

Fig . 2. Colors for the specific indices: 1 - excellent; 2 - very good; 3 - good; 4 - average; 5 - poor; 6 - very poor [5]

In analyzing the data from the annual reports of the regional environmental agencies of Romania, it appears that some of the stations have a low percentage of the validity of the measured data. For example, the validity of PM10 data for 2010 for Giurgiu stations - for GR-2 is $48.3 \%$ and for GR-4 validity is $14.3 \%$. For 20011 for all 4 stations in Giurgiu County the validity of the measured data is below $50 \%$ and therefore, statistical data for PM10 have not been processed. The validity of the measured data for air pollutants in Romanian sector is given in Table 2. The missing data in the table 2 mean that there are no measurements for the corresponding pollutant in the station. These low values of data validity of some of the controlled pollutants lead to incorrect assessment of the air quality in the Romanian section.

Table 2.The validity of the measured data for air pollutants in Romanian sector [5], \%

\begin{tabular}{|c|c|c|c|c|c|c|}
\hline $\begin{array}{c}\text { Monitoring } \\
\begin{array}{c}\text { Stations in } \\
\text { Romania }\end{array}\end{array}$ & $\mathbf{S O}_{\mathbf{2}}$ & $\mathbf{N O}_{\mathbf{2}}$ & $\mathbf{N O}_{\mathbf{x}}$ & $\mathbf{C O}$ & $\mathbf{P M}_{\mathbf{1 0}}$ & $\mathbf{O}_{\mathbf{3}}$ \\
\hline GR-2 & 9.1 & 7.2 & 7.2 & - & - & 11.8 \\
\hline GR-4 & 65.7 & 61.4 & 61.4 & 22.8 & - & 69.8 \\
\hline CL-1 & 92.2 & 14.7 & 14.7 & 69.5 & 17.8 & - \\
\hline CL-2 & 89.6 & - & - & 67.8 & - & 79.6 \\
\hline TR-2 & 96.5 & 92.1 & - & - & 27.6 & 92.4 \\
\hline DJ-1 & - & - & - & - & 38 & - \\
\hline DJ-2 & - & - & - & - & 58 & - \\
\hline
\end{tabular}




\section{Analysis of some main air pollutant in transborder area Bulgaria - Rumania}

The data for the air pollutants for Bulgarian transborder region are taken from the published monthly and quarterly newsletters of Bulgarian Executive Environment Agency and from the daily reports for the state of the environment of Regional Inspectorates for Environmental Protection and Water (RIEPW) located in the Danube basin - Rousse RIEPW, which controls three areas: Ruse, Razgrad and Silistra; RIEPW - Veliko Tarnovo responsible for Veliko Tarnovo and Gabrovo (Gabrovo is not within the Danube region); RIEPW Pleven for Lovech and Pleven (Lovech is not within the Danube region); RIEW Vratsa responsible only for Vratsa, RIEPW - Montana responsible for Montana and Vidin and Regional Inspectorate - RIEPW - Varna responsible for Varna and Dobrich.

The data for air quality in Romanian transborder region are taken from the annual reports of the Romanian Ministry of Environment and Climate Change - National Agency for Environmental Protection [5] and the Regional Environmental Agency in Mehadintsi, Craiova, Olt, Giurgiu, Calarasi, Teleorman and Constanta [7-13].

\subsection{Nitrogen dioxide $\mathrm{NO}_{2}$}

Currently this indicator is measured at seven points of the Bulgarian section. Results of the maximum measured hourly average concentrations are presented in Fig. 3 for four consecutive years - 2011, 2012, 2013 and 2014. It can be seen from this Figure that this contaminant do not exceed the norm for the average eight-hour concentration for the protection of human health which is $200 \mu \mathrm{g} / \mathrm{m}^{3}$. The alarm threshold value of nitrogen dioxide (concentration $400 \mu \mathrm{g} / \mathrm{m}^{3}$, measured over three consecutive hours) also was not exceeded.

An important indicator for human health protection is the average concentration of nitrogen dioxide. The norm of average annual concentration limit value is $40 \mu \mathrm{g} / \mathrm{m}^{3}$. This level was exceeded in several monitoring points. In Pleven there are 10 exceedances during the first quarter of 2014; 4 during 2011 and two during 2012 and 2013. Also there are exceedances in Nikopol - 6 times during 2011, 10 times in Gorna Oryahovitsa during 2012, in Vratsa - 6 exceedances during 2012 and 2 times during 2014 and in Ruse - 5 exceedances during 2011. Exceedances were reported also in Svishtov.

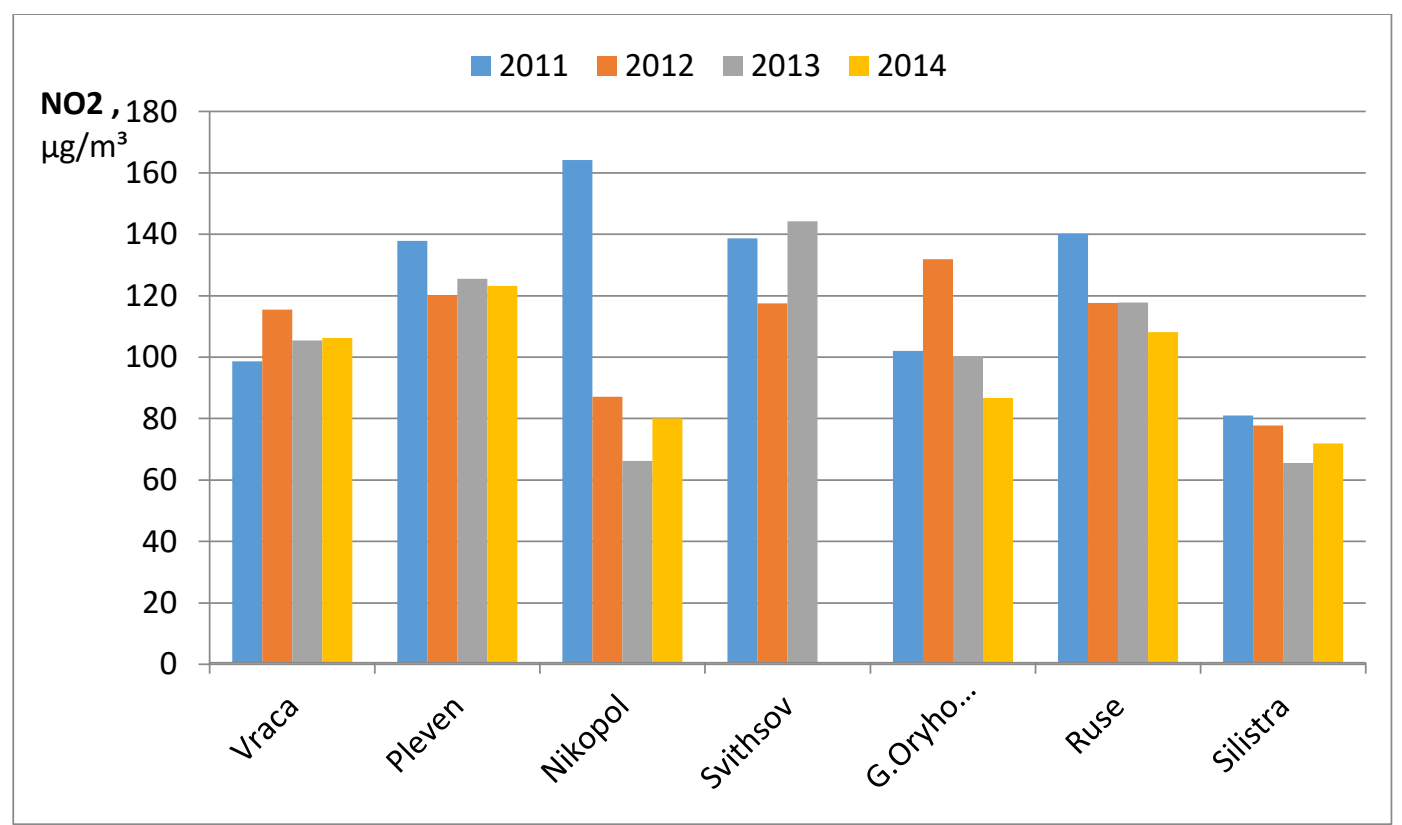

Fige.3. Nitrogen dioxide measured maximal average hourly concentrations.[14] 
It was found that exceedances of the annual average norm $\left(40 \mu \mathrm{g} / \mathrm{m}^{3}\right)$ for concentrations of Nitrogen dioxide $\left(\mathrm{NO}_{2}\right)$ are registered only for agglomerations Bucharest and Brasov, as follows:

For 2011 at the stations:

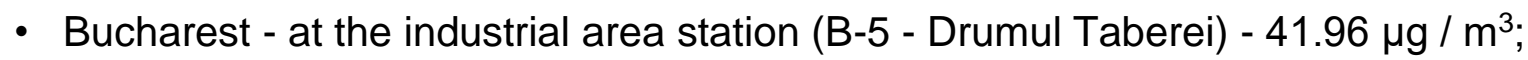

- Braşov - at the traffic station (BV-3 - B - dul Gării) - $56.71 \mu \mathrm{g} / \mathrm{m}^{3}$.

For 2012 only in Bucharest:

- Traffic station B-3 Mihai Bravu - $59 \mu \mathrm{g} / \mathrm{m}^{3}$

- Industrial station B-5 Drumul Taberei- $45 \mu \mathrm{g} / \mathrm{m}^{3}$.

For 2013 in Bucharest and Brasov;

- Traffic station B-3 Mihai Bravu - 60,12 $\mu \mathrm{g} / \mathrm{m}^{3}$;

- Urban background station BV-2 - 51,29 $\mu \mathrm{g} / \mathrm{m}^{3}$.

The hourly limit value for the protection of human health $\left(200 \mu \mathrm{g} / \mathrm{m}^{3}\right)$ is not exceeded more than 18 times per year. There is no exceedance of the value of the alarm thresholds (concentration $400 \mu \mathrm{g} / \mathrm{m}^{3}$, measured for 3 consecutive hours ) for nitrogen dioxide.

Figure 4 shows the results about the measured annual average nitrogen dioxide $\left(\mathrm{NO}_{2}\right)$, registered at monitoring stations in Romania for 2013. From the figure it can be seen that the annual norm for protection of human health $(40 \mu \mathrm{g} / \mathrm{m} 3)$ has been exceeded in 2013 at two points: Bucharest (station B-3 with average 60,12 $\mu \mathrm{g} / \mathrm{m}^{3}$ ) and Brasov ( urban background station BV-2 with average $\left.51,29 \mu \mathrm{g} / \mathrm{m}^{3}\right)$.

At other stations located in the Romanian border area is reported no exceedances of this indicator [4].

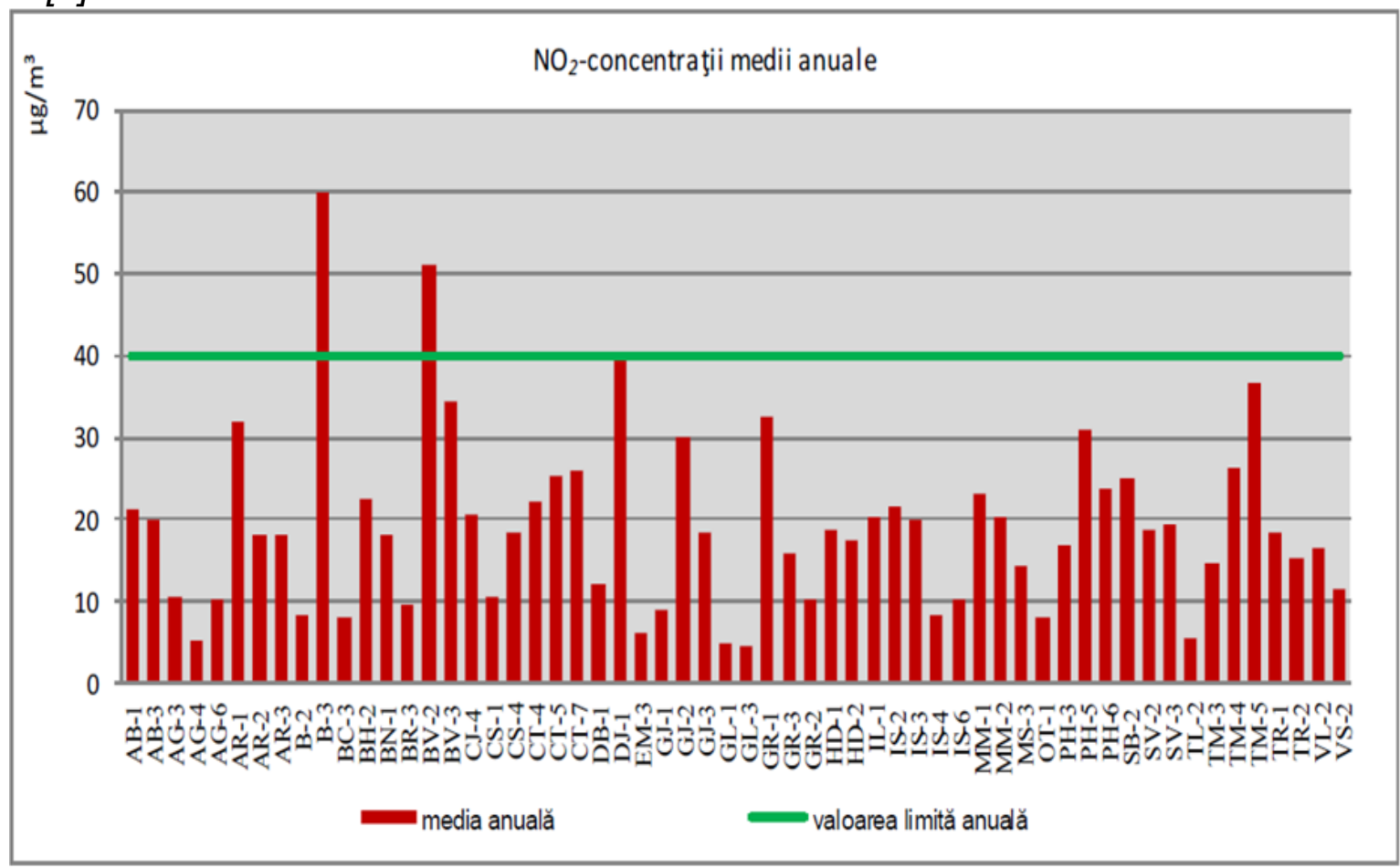

Fig. 4.Nitrogen dioxide $\left(\mathrm{NO}_{2}\right)$ - annual average quantities for 2013 in Romania [4]

\subsection{Sulfur dioxide $\mathrm{SO}_{2}$}

To protect human health in Republic of Bulgaria a maximum hourly rate $-350 \mu \mathrm{g} / \mathrm{m}^{3}$ (averaged over one hour [3]) is accepted. This value must not be exceeded more than 24 times per a calendar year. Also a daily average norm for protection of human health (averaged over 24 hours) is fixed as $125 \mu \mathrm{g} / \mathrm{m}^{3}$. This quantity should not been exceed more than three times per 
a calendar year. The norm for protection of natural ecosystems is $24 \mu \mathrm{g} / \mathrm{m}^{3}$ per calendar year. Alert threshold is $500 \mathrm{\mu g} / \mathrm{m}^{3}$, measured during three consecutive hours.

Maximum average annual concentrations of sulfur dioxide for the period $2011-2014$ year for Bulgarian transborder region are presented graphically in Figure 5 [14].

The figure shows that the highest levels were registered in monitoring point in Vidin, Svishtov and Ruse .- over $40 \mu \mathrm{g} / \mathrm{m}^{3}$. Other points in Bulgarian sector do not report exceedances of maximum average annual concentrations for this four-year period

Exceedances of various norms of sulfur dioxide for the period 2011 - 2013 for all monitoring stations in Romanian transborder region have not been reported.

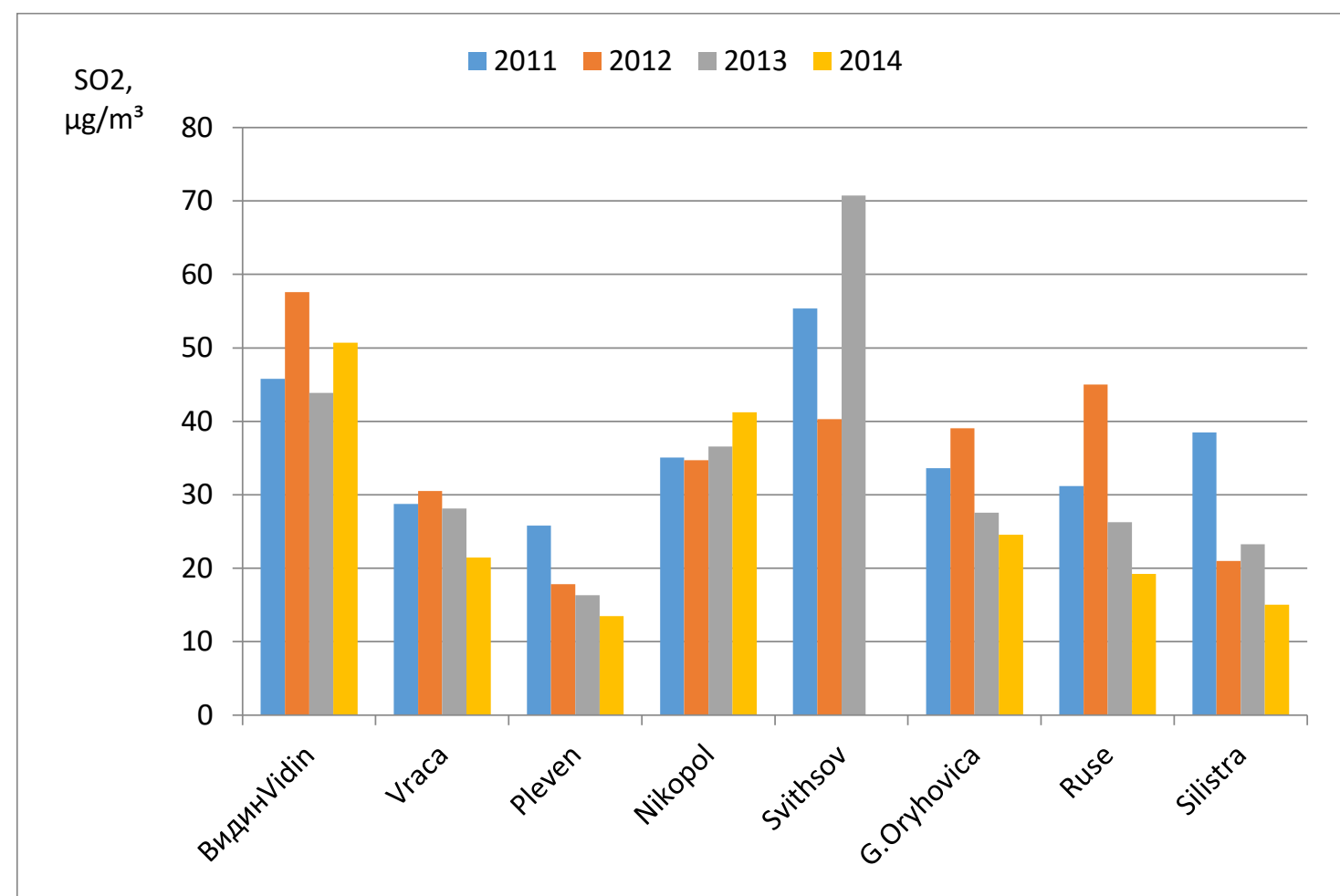

Fig. 5. Sulfur dioxide $\mathrm{SO}_{2}$ - measured maximum average annual concentrations for Bulgarian transborder region for 2011, 2012, 2013 and 2014 [14]

\subsection{Particle matter}

According to the Ordinance № 12 / 2010 average maximum levels for contamination with $\mathrm{PM}-10$ is $40 \mathrm{mg} / \mathrm{m}^{3}$.

Figure 6 shows the results of measuring the average annual concentrations of PM10 for Bulgarian sector for the period $2011-2014$ [14].

It is evident that the measured concentrations significantly exceed the average quantity of $40 \mathrm{mg} / \mathrm{m}^{3}$ for almost all monitoring points in Bulgarian section. Under this norm are only two points - in Silistra (for this four-year period), and in Dobrich (for 2013 and 2014). 


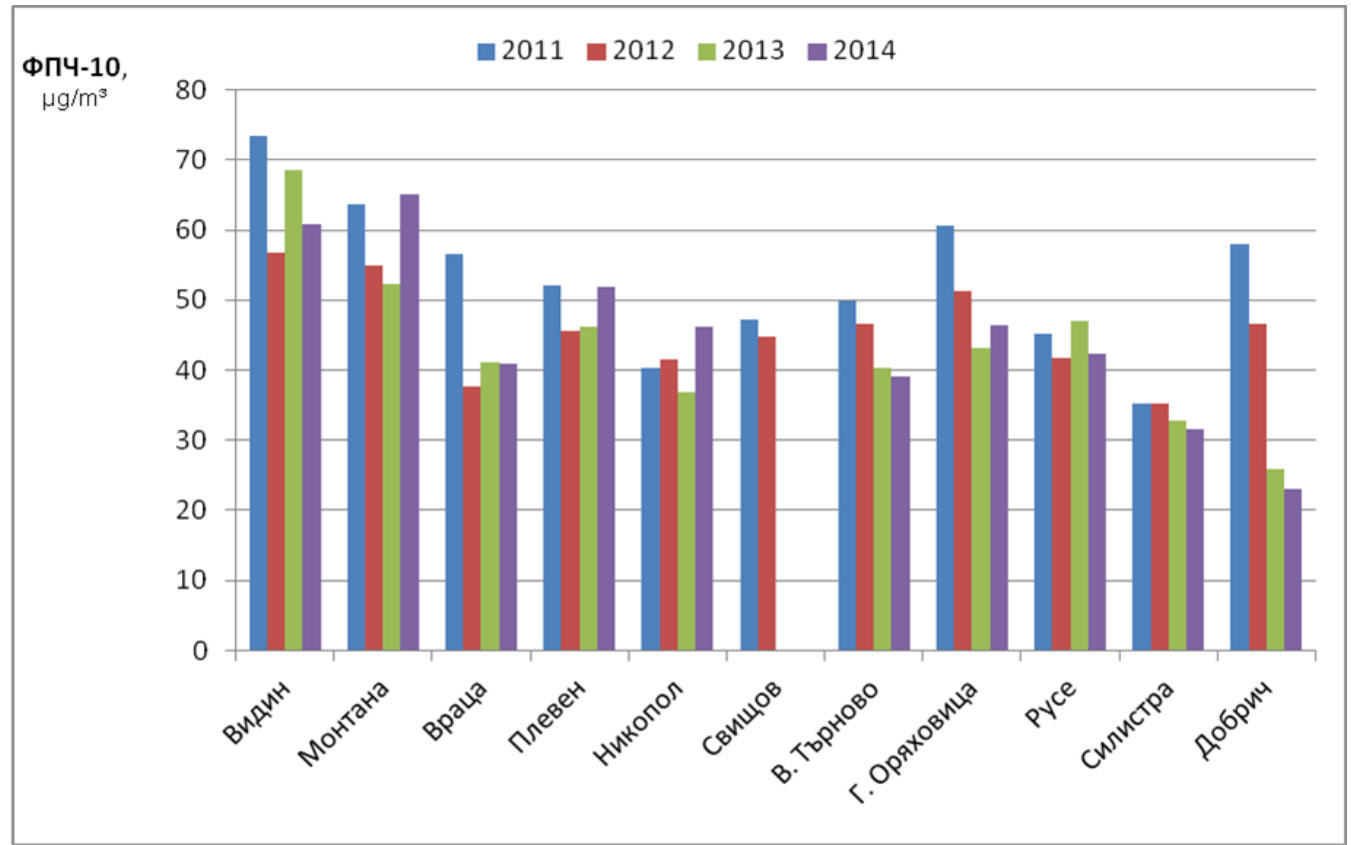

a)

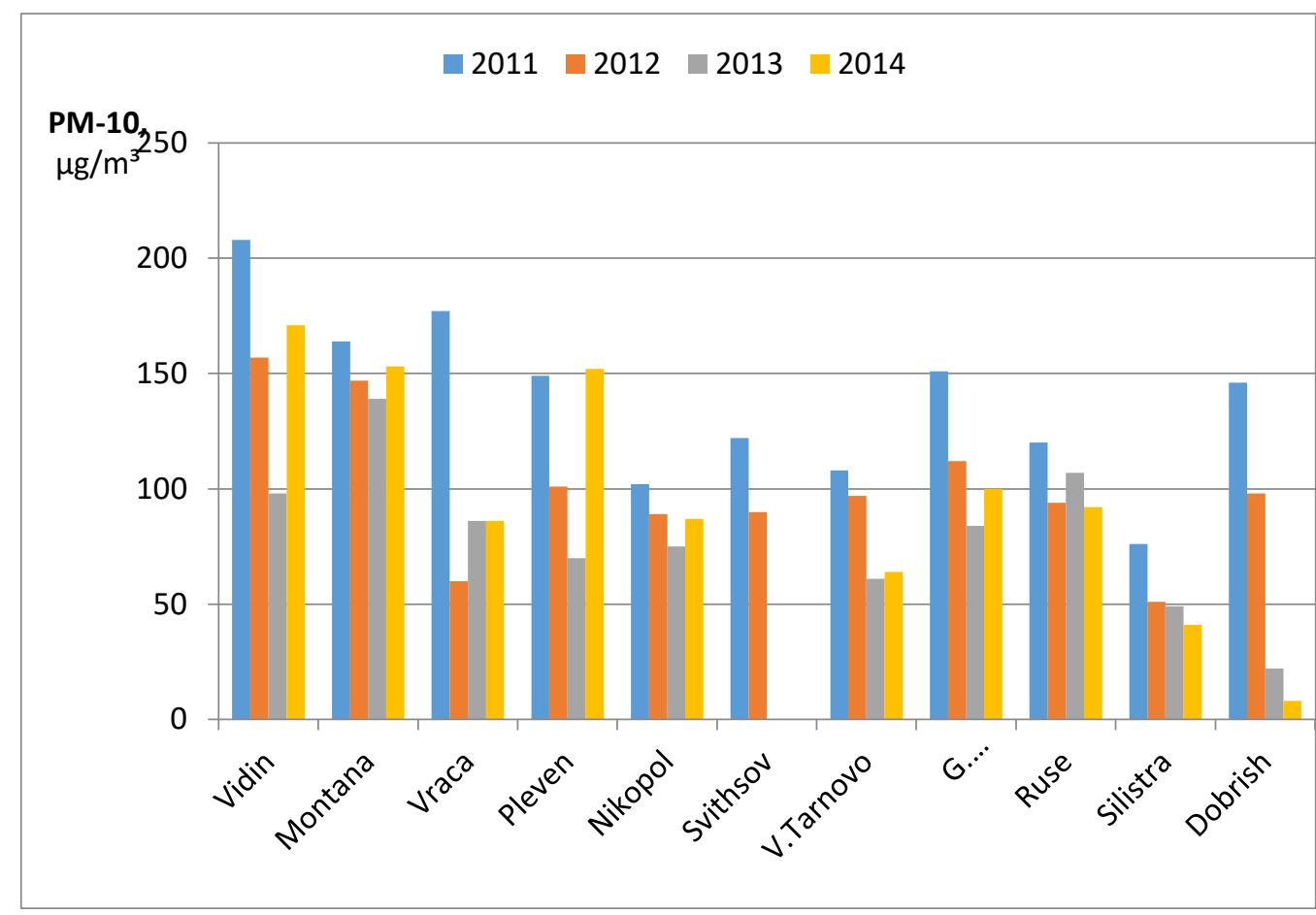

b)

Fig. 6. PM-10 reported by stations in Bulgaria for the period $2011-2014$ a) average annual concentrations b) hourly average concentrations [14] 


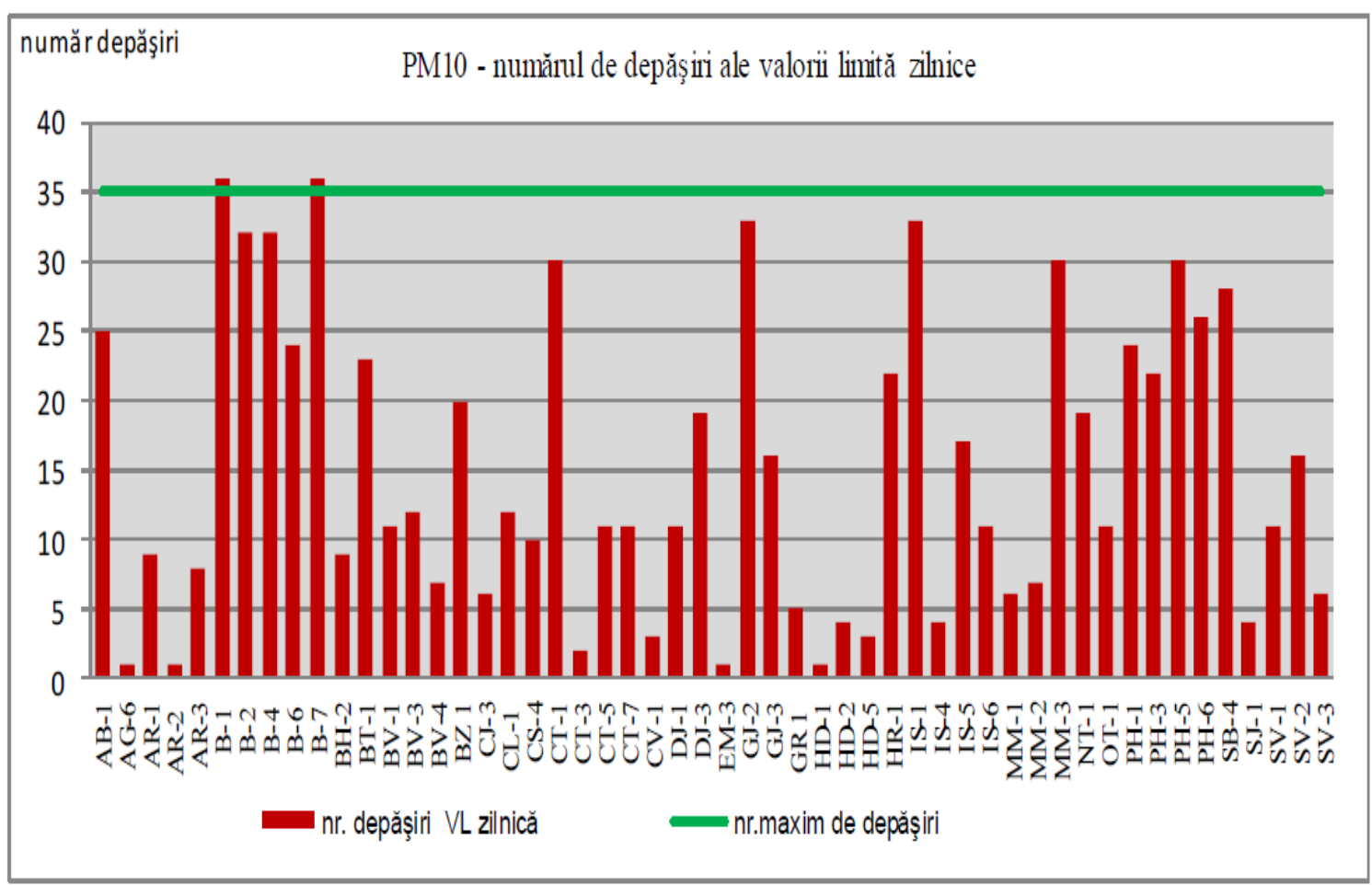

Fig. 7. Number of exceedances of PM-10 concentrations above $50 \mathrm{mg} / \mathrm{m}^{3}$ per a year recorded by monitoring stations in Romania for 2013 [4 ].

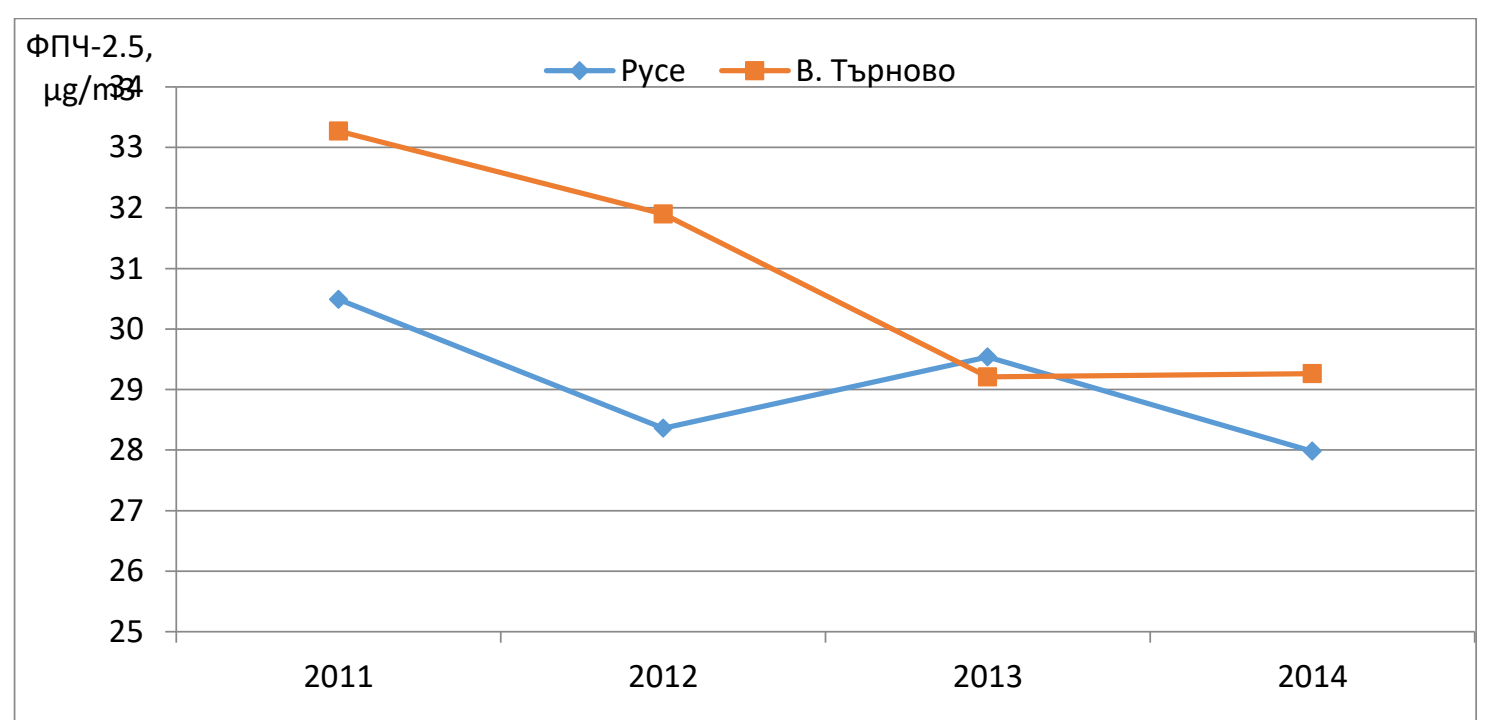

Fig. 8. PM-2.5 - average annual concentrations reported by stations in Ruse and Veliko.

\section{Tarnovo, Bulgaria [14]}

The number of exceedances of PM10 concentration above $50 \mu \mathrm{g} / \mathrm{m}^{3}$ per a year recorded by the monitoring stations of Romania for 2013 [4] is shown in Figure 7.

From this figure it can be seen that in 2013 in Romania the number of exceedances is greater than 35 times per a year only for two monitoring stations: Urban background station B-1 in Bucharest, which registered 36 exceedances and Suburban station B-7 in Magurele, Ilfov County also with 36 exceedances.

In Bulgaria PM-2.5 pollution is observed in 10 monitoring points. Only two of them - Ruse and Veliko Tarnovo are in the Bulgarian trans border section. Figure 8 shows the measured annual average PM2.5 concentrations in Ruse and Veliko Tarnovo for the period 2011 - 
2014.These concentrations are less than the annual norm of $40 \mathrm{mg} / \mathrm{m}^{3}$ for the whole 4 year period.

In Romania PM2.5 concentrations are measured in three monitoring stations - $\mathrm{MH}-1$ in Mehadintsi, DJ-2 in Craiova and CT-2 in Constanta. In Romania, the annual limit value plus the margin of tolerance in 2013 is $26 \mu \mathrm{g} / \mathrm{m}^{3}$ (allowance for 2013 is $1 \mu \mathrm{g} / \mathrm{m}^{3}$ ). This figure shows that in 2013 all stations in Romania has not reported exceeding of the allowable average annual concentrations. It is clear also that many of the stations have recorded significantly lower values than permitted.

\section{Conclusions}

1. A good monitoring system that controls air quality is functioning in the border region Bulgaria - Romania. In Romania, this system is fully automated and in Bulgaria the automation is about $80 \%$.

2. The proportion of background pollution, which is commensurate with the proportion of pollution from the residential sector, is still high. These contaminants are the main sources which form the common dust pollution in the border region. High share of pollutants falls to the suspended particles.

3. The warning systems and the systems for expressing the results of specific measurements of air quality have to be improved so that the public to be informed more easily It is logical these systems to be similar or identical, since both countries are governed by the same requirements set out by EU directives, which are also incorporated in their national laws.

\section{References}

1. Council Directive 1996/62/EC on the assessment and management of the quality of ambient air

2. Directive 2008/50 / EC of the European Parliament and of the Council 21 May 2008 on ambient air quality and cleaner air for Europe.

3. Ordinance № 12 of 15 July 2010 on standards for sulfur dioxide, nitrogen dioxide, particulate matter, lead, benzene, carbon monoxide and ozone in ambient air Prom. SG. No.58 of July 30, 2010.

4. Raport național privind starea mediului anul 2013. Ministerul mediului și schimbărilor climatice. Agenţia naţională pentru protecţia mediului, Bucureşti, 2014

5. Reteaua Nationala de Monitorizare a Calitatii Aerului (RNMCA) -http://www.calitateaer.ro

6. Национална система за контрол качеството на атмосферния въздух в реално време ИАОС -http://pdbase.government.bg/airq/bulletin.jsp

7. Raportul anual privind starea mediului în judetul Mehedinti -2011,2012,2013 and 2014. Agenţia regională de protecţie a mediului Mehedinţi. Website: www.apmmh.ro

8. Raport preliminar privind calitatea aerului în aglomerarea Craiova- 2011, 2012,2013 and 2014. Agenţia regională de protecţie a mediului Craiova. Website: www.apmdj.ro

9. Raport preliminar privind starea mediului on judetul Olt on anul $-2011,2012,2013$ and 2014. Agenţia regională de protecţie a mediului Olt. Website: www.apmot.ro

10. Raport anual privind starea mediului în judeţul Teleorman-211, 2012, 2013 and 2014. Agenţia regională de protecţie a mediului Teleorman. Website: www.apmtr.ro Email: office@apmtr.ro

11. Raport preliminar privind calitatea aerului inconjurator pentru anul -2011, 2012, 2013 and 2014. Agenţia regională de protecţie a mediului Giurgiu. Website: www.apmgr.ro Email: office@apmgr.ro 
12. Raportul anual privind starea factorilor de mediu în judeţul Călăraşi în anul- 2011, 2012, 2013 and 2014. Agenţia regională de protecţie a mediului Călăraşi. Website: www.apmcl.ro Email: office@apmcl.ro

13. Raportul privind starea factorilor de mediu pe anul- 2011, 2012, 2013 and 2014. Agenţia regională de protecţie a mediului Constanţa. Website: www.mediu-constanta.ro Email: office@mediu-constanta.ro

14. Тримесечен бюлетин за състоянието на околната среда за периода 2011- 2014 год. ИAOC http://pdbase.government.bg/airq/bulletin.jsp 